\title{
MANAJEMEN RISIKO LIKUIDITAS DI BMT AL IZZAH NGORO MOJOKERTO NGORO MOJOKERTO JAWA TIMUR
}

\author{
Oleh \\ Lu' lu' il Maknuun, SE, MM \\ E-mail luluilmaknuun92@gmail.com
}

\begin{abstract}
:
The purpose of this research is to find out whether the liquidity risk management applied by BMT Al IZZAH Ngoro Mojokerto. The research method used is descriptive qualitative. Unit of analysis is liquidity risk management applied by BMT Al IZZAH Ngoro Mojokerto. Data processing techniques in this research based on Miles and Huberman.

Research results can be concluded that BMT Al IZZAH Ngoro Mojokerto in performing risk identification use historic approach and emerge a pattern of yearly cycles and mapping the cash flow. Liquidity risk categorized in third quadrant with low frequency occurs and give severe impact while the risk is come. Risk mitigation focused in preventive action in order to avoid liquidity risk and develop contingency plan. BMT Al IZZAH Ngoro Mojokerto performing monitoring and controlling of liquidity risk, are supported by technology and come along with held an appointment regularly with all employees discuss about financial condition in $B M T$.
\end{abstract}

Keywords: Cooperation, Baitul Maal wa Tamwiil, Risk Management, Liquidity Risk.

\section{PENDAHULUAN}

\section{A. Latar Belakang Masalah}

Indonesia merupakan negara dengan mayoritas penduduknya beragama islam dan sebagai negara dengan mayoritas penduduk muslim terbesar di dunia, Indonesia dalam menjalankan roda perekonomiannya menggunakan prinsip ekonomi kerakyatan. Ekonomi kerakyatan merupakan bentuk keberpihakan kebijakan ekonomi pemerintah kepada rakyat. Pengembangan ekonomi kerakyatan sendiri erat kaitannya dengan pengembangan ekonomi umat Islam.

Undang-Undang Dasar 1945 pada pasal 33 menyebutkan bahwa perekonomian disusun sebagai usaha bersama yang berdasar dengan asas kekeluargaan. Pasal di atas tersirat makna bahwa kemakmuran sosial lebih diutamakan daripada kemakmuran individual. Koperasi sebagai salah satu lembaga keuangan bukan bank memiliki peranan yang penting dalam satu negara, khususnya negara yang sedang berkembang seperti Indonesia. Salah satu peran strategis koperasi ini yaitu membantu dalam pengembangan kegiatan ekonomi lokal dan pemberdayaan masyarakat. Bentuk pengembangan kegiatan ekonomi lokal salah satunya dengan memberikan akses pendanaan kepada usaha mikro, kecil, dan menengah.

Salah satu lembaga keuangan non bank yang berbadan hukum koperasi adalah Baitul Maal wa Tamwil (BMT). Menurut Salah satu pakar ekonomi Sudarsono (2012:107) berpendapat bahwa BMT terdiri dari dua istilah yaitu baitul maal dan baitul tamwil. Baitul maal lebih mengarah pada usaha-usaha pengumpulan dan penyaluran dana yang non-profit, seperti zakat, infaq, shadaqah. Sedangkan baitul tamwil sebagai usaha pengumpulan dan penyaluran dana komersial. Usaha-usaha tersebut merupakan usaha yang mendukung kegiatan ekonomi masyarakat kecil yang berlandaskan prinsip Syariah. Dengan berbadan hukum koperasi, BMT dapat menghimpun dana dari para anggotanya dan disalurkan kembali dalam bentuk pembiayaan untuk mengembangkan usahanya dengan prinsip Syariah. Salah satu prinsip Syariah yaitu melarang adanya praktek riba sesuai dengan sural

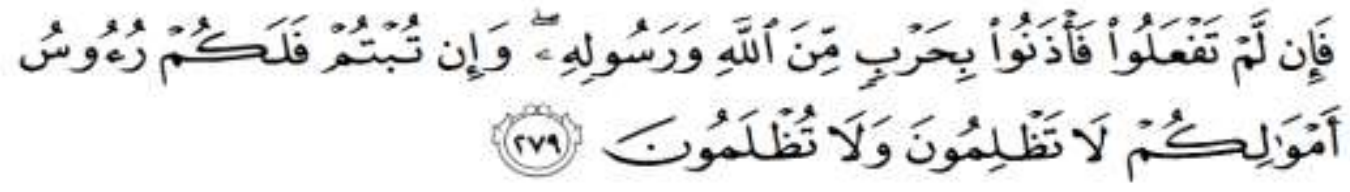


"Maka jika kamu tidak mengerjakan (meninggalkan sisa riba), maka ketahuilah, bahwa Allah dan Rasul-Nya akan memerangimu. Dan jika kamu bertaubat (dari pengambilan riba), maka bagimu pokok hartamu; kamu tidak menganiaya dan tidak (pula) dianiaya."(Departemen Agama, 2001: 100)

Manajemen risiko dinilai sangat penting sebab pada dasarnya kegiatan intermediasi merupakan bisnis kepercayaan dimana dana dari pada pihak yang menyimpan dananya pada lembaga keuangan, lalu pihak lembaga keuangan menyalurkan dalam bentuk pembiayaan kepada pihak yang membutuhkan. Arifin (2005: 60) menjelaskan bahwa risiko likuiditas adalah ketidakmampuan lembaga keuangan untuk memenuhi kewajiban jangka pendeknya. Simpanan anggota merupakan kewajiban bagi pihak BMT.

Dari sisi pendanaan, penyimpan dana tentunya mengharapkan dana yang di titipkan dapat ditarik setiap saat. Untuk itu lembaga keuangan BMT harus memperhatikan dan dapat mengatur likuiditasnya sehingga kepercayaan dari anggota dapat terjaga.

Selain itu, menurut Peraturan Menteri nomor 35.3/Per/M.KUKM/X/2007, bab 2, pasal 4, poin C, dikatakan bahwa:

"KJKS dan UJKS Koperasi adalah alat dari rumah tangga anggota untuk mandiri dalam mengatasi masalah kekurangan modal (bagi anggota pengusaha) atau kekurangan likuiditas (bagi anggota rumah tangga) sehingga berlaku asas menolong diri sendiri (self help).”

Sesuai dengan kutipan peraturan di atas, menguatkan bahwa BMT harus menanggulangi sendiri risiko likuiditas yang di hadapi dengan mengerahkan segala upaya guna menyelamatkan diri sendiri dari ancaman risiko yang di hadapi.

BMT Al IZZAH Ngoro Mojokerto merupakan BMT di daerah Jawa Timur yang sedang berkembang pesat. BMT AL IZZAH mengalami pertumbuhan hingga 92\% dalam kurun waktu kurang dari 2 tahun dalam rentang waktu 2012 hingga Juni 2014. Jumlah anggota simpanan sebesar 20.204 orang hingga Desember 2014. Berkembangnya BMT hendaknya dibarengi dengan manajemen risiko likuiditas yang baik. Untuk melihat kemampuan likuiditasnya, digunakan rasio kas. Pada tahun 2012, rasio kas BMT Al IZZAH Ngoro Mojokerto berada pada posisi 34,46\%. Selain itu, tidak adanya instrument khusus dalam bantuan likuiditas di BMT membuat BMT harus melakukan segala upaya untuk menjaga likuiditasnya.

Berdasarkan dari penjelasan di atas,maka mendorong penulis untuk melakukan penelitian terkait dengan manajemen risiko likuiditas pada BMT. Tujuan dari penelitian ini adalah untuk mengetahui bagaimana manajemen risiko likuiditas di BMT Al IZZAH Ngoro Mojokerto

\section{LANDASAN PUSTAKA}

A. Baitul Mal wa Tamwil

Baitul Maal wa Tamwil, atau biasa dikenal dengan sebutan BMT adalah lembaga keuangan yang secara nyata memiliki dua bidang kegiatan sekaligus, yaitu sebagai pengelola ZIS (social oriented) dan menjalankan perbankan syariah (profit oriented). Bila salah satu diantaranya tidak ada, maka tidak boleh disebut BMT melainkan Baitul Maal atau Baituttamwil saja. Keduanya merupakan suatu sistem dalam wadah BMT yang bekerja sinergi dan tidak dapat dipisahkan satu sama lain, dengan demikian sebuah lembaga keuangan tidak bisa disebut BMT apabila secara nyata Baitul Maalnya tidak ada, dan atau Baitut-tamwilnya tidak tunduk mengikuti prinsip syariah. Usaha-usaha tersebut menjadi bagian 
yang tidak terpisahkan dari BMT sebagai lembaga yang mendukung kegiatan ekonomi masyarakat kecil yang berlandaskan prinsip Syariah (Sudarsono, 2008: 107).

Dari beberapa pengertian di atas dapat disimpulkan bahwa BMT sebagai lembaga keuangan bukan bank yang terbagi atas dua fungsi yaitu Baitul Maal (Rumah Harta) berfungsi sebagai pengelola dana sosial sesuai dengan peruntukannya dan Baitul Tamwil (Rumah pengembangan harta) sebagai pelaksana fungsi bisnis untuk mengembangkan usaha produktif dari proses penghimpunan dana dari masyarakat.

\section{B. Manajemen}

Manajemen adalah seni menyelesaikan pekerjaan melalui orang lain. Definisi Mary Parker Follet ini berarti bahwa seorang manajer bertugas mengatur dan mengarahkan orang lain untuk mencapai tujuan organisasi. Daft (2007: 6) menyatakan bahwa manajemen adalah pencapaian tujuan organisasi dengan cara yang efektif dan efisien melalui perencanaan, pengorganisasian, pengarahan, dan pengendalian sumber daya organisasi.

Dari pernyataan di atas, maka dapat disimpulkan terdapat dua ide penting dalam manajemen adalah: Pertama, terdapat empat fungsi manajemen yaitu (Daft, 2007: 7-9):

\section{Perencanaan (Planing)}

Perencanaan adalah fungsi manajemen yang menentukan tujuan untuk kinerja organisasi di masa depan serta memutuskan tugas dan penggunaan sumber daya yang diperlukan untuk mencapai tujuan tersebut.

\section{Pengorganisasian (Organizing)}

Fungsi manajemen yang berkaitan dengan penentuan dan pengelompokan tugas ke dalam departemen, penentuan otoritas dan alokasi sumber daya di antara organisasi.

\section{Pengarahan (Direction)}

Kegiatan dimana menggunakan pengaruh untuk memotivasi karyawan untuk mencapai tujuan organisasi. Pengarahan ini erat kaitannya dengan kepemimpinan.

\section{Pengendalian (Controling)}

Fungsi manajemen yang berkaitan dengan mengawasi aktivitas organisasi, menentukan apakah organisasi tetap dalam jalur yang ditentukan untuk mencapai targetnya, serta melakukan koreksi bila diperlukan. Kedua, terdapat pencapaian tujuan organisasi dengan cara efektif dan efisien.

Pada gambar 1 menggambarkan keempat fungsi organisasi yang saling berkaitan.

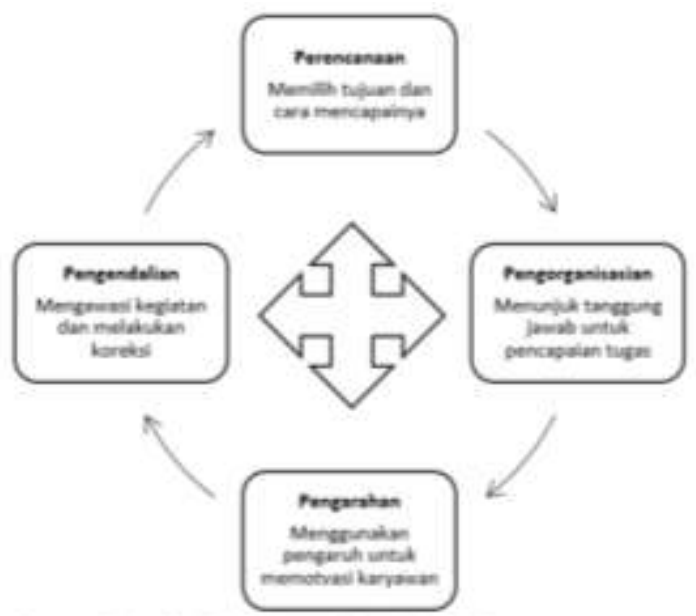




\section{Risiko}

Risiko diartikan sebagai bentuk peristiwa yang memiliki pengaruh terhadap kemampuan seseorang atau institusi untuk mencapai tujuannya. Bank Indonesia mendefinisikan risiko sebagai potensi terjadinya peristiwa yang dapat menimbulkan kerugian bank (Tampubolon, 2004: 19-20). Agrawal (2009: 6) menjelaskan risiko adalah konsep yang menunjukkan efek negatif kepada aset atau sesuatu yang bernilai yang mungkin timbul dari proses yang sedang dilakukan atau yang akan datang.

Dari penjelasan di atas, dapat disimpulkan bahwa risiko merupakan suatu peristiwa yang berpotensi memberikan efek negatif yang muncul dari suatu tindakan baik yang sedang dilakukan maupun tindakan yang yang dilakukan di masa mendatang.

D. Risiko dalam Islam

Manusia pada dasarnya tidak dapat memastikan apa yang akan terjadi di masa mendatang. Manusia hanya dapat memprediksi berdasarkan pengamatannya, termasuk memprediksi kerugian yang mungkin terjadi di masa depan. Kerugian sendiri merupakan bentuk dari risiko yang merupakan Sunnatullah atau ketetapan Allah. Islam mengakui bahwa kematian, kecelakaan, kerugian merupakan takdir dari Allah. Hal-hal seperti ini tentunya tidak dapat ditolak, namun kita sebagai manusia diperintahkan untuk membuat perencanaan untuk menghadapi ketidakpastian di masa depan. Hal ini ini telah tercantum dalam firman Allah pada surah Al-Hashr ayat 18 sebagai berikut:

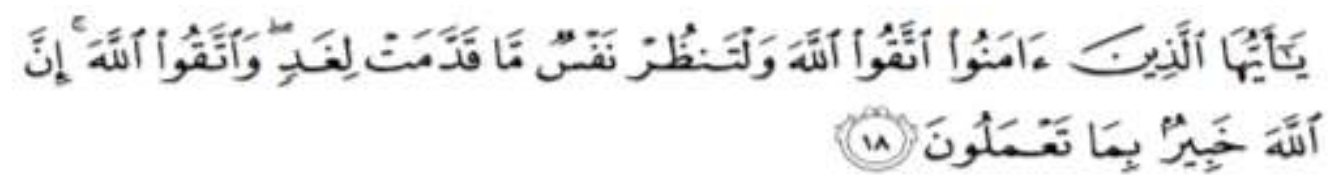

"Hai orang-orang yang beriman, bertakwalah kepada Allah dan hendaklah setiap diri memperhatikan apa yang telah diperbuatnya untuk hari esok (akhirat); dan bertakwalah kepada Allah, sesungguhnya Allah Maha Mengetahui apa yang kamu kerjakan.” (Departemen Agama, 2001: 1242)

Dalam ayat di atas, Allah memerintahkan manusia untuk menyiapkan dan melakukan perencanaan berdasarkan situasi dan kondisi yang telah di amati baik pada masa lampau, saat ini, serta prediksi di masa mendatang agar potensi kerugian dapat di minimalisir.

Dalam kaidah fiqh muamalah, Mudjib (2001: 70) menuliskan terdapat prinsip muamalah yaitu "hasil usaha muncul bersama biaya/hak mendapatkan hasil disebabkan oleh keharusan menanggung kerugian" (al kharaj bi al dhoman) dan juga prinsip "profit muncul bersama risiko/risiko itu menyertai manfaat" (al ghunmu bi al ghurmi) (Djazuli, 2006: 133)

\section{E. Manajemen Risiko}

Manajemen risiko adalah suatu pendekatan terstruktur atau metodologi dalam mengelola ketidakpastian yang berkaitan dengan ancaman, suatu rangkaian aktivitas manusia termasuk, Penilaian risiko, pengembangan strategi untuk mengelolanya dan mitigasi risiko dengan menggunakan pemberdayaan atau pengelolaan sumberdaya. Menurut Warburg (2004, dalam Hanafi, 2009: 18) menyatakan bahwa manajemen risiko adalah seperangkat kebijakan, prosedur yang lengkap, yang dimiliki oleh organisasi untuk mengelola, memonitor, dan mengendalikan eksposur organisasi terhadap risiko.

Dapat disimpulkan dari pernyataan diatas bahwa manajemen risiko merupakan serangkaian prosedur yang terdiri dari beberapa hal proses identifikasi, mengukur risiko dan memantau risiko 
dalam rangka memanajemen risiko agar suatu organisasi dapat bertahan sehingga tidak sampai memberikan kerugian.

Rivai, dkk (2007: 27-29) menjabarkan bagaimana tahapan dari proses manajemen risiko berjalan yaitu terdiri dari beberapa proses seperti pada gambar berikut:

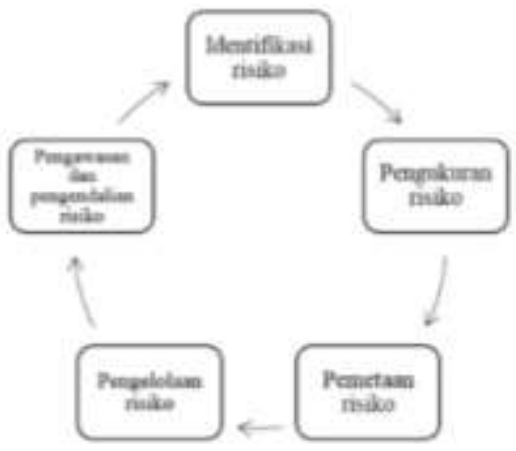

Sumber: Rival, Veithzal dikk. 2007. Bank

and Financial Institution Management:

Conventionat and Sharia System, Hat 27-29

diolah

\section{F. Likuiditas}

Likuiditas adalah kemampuan manajemen suatu lembaga keuangan dalam menyediakan dana yang cukup untuk memenuhi kewajibannya setiap saat (Rivai, 2013: 145). Kewajiban yang dimaksud seperti penarikan yang tidak terduga oleh para deposan yaitu penarikan commitment loan. Suatu lembaga keuangan dapat diketahui tingkat keberhasilannya dalam manajemen likuiditas jika dilihat dari (Rivai, 2013: 145):

1. Kemampuan dalam memprediksi kebutuhan dana di waktu yang akan datang.

2. Kemampuan untuk memenuhi permintaan akan cash dengan menukarkan harta lancarnya;

3. Kemampuan memperoleh cash secara mudah dengan biaya yang sedikit;

4. Kemampuan pendataan pergerakan cash in dan cash out dana (cash flow);

5. Kemampuan untuk memenuhi kewajibannya tanpa harus mencairkan aktiva tetap apapun ke dalam cash.

G. Risiko Likuiditas

Kekurangan likuiditas dapat mengarahkan suatu lembaga keuangan kepada kegagalan meskipun dalam tingkat solven. Committee of European Banking Supervisors (dalam Jorion, 2011: 640) membagi risiko likuiditas menjadi dua, yaitu:

\section{Risiko Likuiditas Aset (Asset Liquidity Risk)}

Risiko Likuiditas Aset merupakan risiko dimana berada di posisi yang tidak mudah untuk melakukan offsetting posisi tertentu dalam waktu singkat tanpa secara signifikan mempengaruhi harga pasar, karena ketidakcukupan likuiditas di pasar atau terjadi gangguan pasar.

\section{Risiko Likuiditas Pendanaan (Funding Liquidity Risk)}


Risiko Likuiditas Pendanaan yaitu risiko yang timbul dari ketidakmampuan lembaga keuangan untuk memenuhi kewajibannya dan kewajiban yang datang tanpa menimbulkan kerugian yang tidak dapat diterima.

H. Teori Manajemen Likuiditas

Pada umumnya, terdapat empat macam teori likuiditas yang dikenal, yaitu sebagai berikut (Rivai, 2013: 146):

\section{Commercial Loan Theory}

Teori ini beranggapan bahwa bank hanya boleh memberikan pinjaman "dengan surat dagang jangka pendek yang dapat dicairkan dengan sendirinya (self liquidating)". Self liquidating berarti pemberian pinjaman mengandung makna untuk pembayaran kembali.

\section{Shiftability Theory}

Teori ini beranggapan bahwa likuiditas sebuah bank tergantung pada kemampuan bank

memindahkan aktivanya ke orang lain dengan harga yang dapat diramalkan.

3. Anticipated Income Theory

Teori ini berarti semua dana yang dialokasikan atau setiap upaya pengalokasian dana ditujukan pada sektor yang feasible dan layak yang akan menguntungkan bagi bank.

4. The Liability Management Theory

Teori ini melihat bagaimana bank dapat mengelola pasivanya sedemikian rupa sehingga pasiva itu dapat menjadi sumber likuiditas.

Adapun likuiditas yang diperlukan adalah: (1) untuk menghadapi penarikan oleh nasabah; (2) memenuhi kewajiban yang jatuh tempo; (3) memenuhi permintaan pembiayaan dari nasabah.

\section{Proposisi}

Penelitian ini di dasarkan atas proposisi, bahwa BMT seharusnya melakukan manajemen risiko likuiditas secara optimal agar terhindar dari risiko likuiditas.

\section{METODE PENELITIAN}

Metode penelitian yang digunakan dalam penelitian ini adalah pendekatan kualitatif deskriptif dengan jenis penelitian studi kasus. Unit analisis dalam penelitian ini adalah manajemen risiko likuiditas di BMT Al IZZAH Ngoro Mojokerto. Teknik analisis yang digunakan dalam penelitian ini adalah reduksi data, penyajian data, serta kesimpulan dan verifikasi. Dari hasil penelitian akan di deskripsikan dalam bentuk uraian, bagan, dan flowchart.

\section{HASIL dan PEMBAHASAN}

BMT Al IZZAH Ngoro Mojokerto ini berdiri atas inisiatif dari Departemen Sosial yang menyarankan untuk mendirikan suatu lembaga keuangan karena kekhawatiran atas hilangnya sejumlah dana yang nantinya akan menjadi modal BMT. Bergerak atas dasar hal ini, maka lahirlah sebuah gagasan untuk mendirikan Lembaga Keuangan Mikro Syariah (LKMS) berbentuk Koperasi Balai Usaha Mandiri Terpadu atau Baitul Mal wa Tamwil (BMT) yang dalam anggaran dasar disebut dengan Koperasi BMT AL IZZAH. Pada tahun 2006, tepatnya pada tanggal 13 Juni 2006 telah memiliki badan hukum dengan nomor 
03.BH/403.62/IV/2006. Seiring dengan berjalannya waktu, sejauh ini terjadi banyak peningkatan baik secara operasional dan jumlah dana yang berhasil di himpun. Dari sisi operasional, BMT Al IZZAH Ngoro Mojokerto telah menggunakan Teknologi Informasi untuk menunjang kinerjanya. Teknologi yang digunakan adalah sistem Monitoring cabang dengan menggunakan media internet dengan team viewer. Team viewer ini bermanfaat agar kantor pusat memonitor transaksi keuangan di setiap cabang secara realtime, agar ketika Cabang mengalami kendala dalam sisi keuangan, kantor pusat apa bergerak cepat dan efisien. Selain itu, BMT Al IZZAH Ngoro Mojokerto menggunakan sistem yang dimiliki oleh Negakom dalam melakukan transaksi yang bersifat Mobile. Sistem ini memudahkan para petugas BMT Al IZZAH Ngoro Mojokerto untuk bisa terjun langsung ke pasar-pasar di sekitar wilayah operasional BMT untuk memudahkan transaksi oleh para anggota. Transaksi yang dimaksud seperti pembayaran cicilan, penyetoran tabungan, maupun penarikan tabungan. Menggunakan alat serupa EDC (Electronic Data Capture), para anggota yang melakukan transaksi akan mendapatkan print-out sebagai bukti transaksi yang sah. Tujuan dari menggunakan sistem ini adalah untuk memberikan kemudahan dan kenyamanan bertransaksi bagi anggota BMT Al IZZAH Ngoro Mojokerto yang memiliki moto "MUDAH", yaitu mudah dalam melakukan transaksi, aman dalam produk yang dimiliki, serta halal dan tidak mengandung riba dari praktiknya. BMT yang memiliki visi "Menjadi keuangan Mikro Syari'ah yang sehat, berkembang, dan terpercaya yang mampu melayani anggota masyarakat sekitar berkehidupan salam, penuh keselamatan, kedamaian dan kesejahteraan" dan memiliki misi "Mengembangkan Koperasi BMT Al IZZAH Ngoro Mojokerto sebagai sarana gerakan pemberdayaan dan keadilan, sehingga terwujud kualitas masyarakat di sekitar Koperasi BMT Al IZZAH Ngoro Mojokerto yang salam, penuh keselamatan, kedamaian dan kesejahteraan" ini memiliki 16 kantor cabang yang tersebar di kabupaten Mojokerto. Pada proses penyelesaian penelitian ini, penulis melakukan penggalian informasi kepada Manajer BMT Al IZZAH Ngoro Mojokerto yang merupakan key informan dalam penelitian ini. Dari Key informan diharapkan mendapatkan informasi tentang gambaran umum BMT Al IZZAH Ngoro Mojokerto, mekanisme manajemen likuiditas, sistem manajemen risiko likuiditas dari BMT. Selain itu, wawancara dilakukan kepada kepala bagian pembiayaan sebagai informan 1 untuk menguatkan penjelasan dari Key informan. Dalam kegiatan operasional BMT Al IZZAH Ngoro Mojokerto telah dihadapkan oleh situasi di mana BMT berpotensi mengalami risiko likuiditas. Pengelolaan likuiditas merupakan hal vital bagi lembaga keuangan sebagai lembaga yang mendapat kepercayaan serta amanah dari para anggotanya. Manajemen risiko likuiditas meliputi suatu siklus yang dimulai dengan melakukan identifikasi, penilaian, mitigasi, dan pengawasan. Dalam melakukan identifikasi, penulis melakukan wawancara dengan pihak BMT dan menemukan bahwa pada saat menjelang bulan Ramadhan akan berpotensi mengalami risiko likuiditas. selain itu, dilakukan pemetaan terhadap aktivitas kas kantor cabang dan pusat seperti gambar 3. Dari hasil melakukan pemetaan terhadap aliran kas, di dapatkan sumber-sumber potensi terjadinya risiko likuiditas yaitu di kelompokkan ke dalam 4 kategori yaitu yang disebabkan dari aktivitas pendanaan, aktivitas kantor cabang, aktivitas pembiayaan, dan konversi antara kas dan bank. Untuk itu, pihak BMT Al IZZAH Ngoro Mojokerto melakukan retensi terhadap risiko likuiditas yang dihadapi. Retensi risiko yangdimaksud adalah Active Retention (Retensi aktif), sebab pihak BMT Al IZZAH Ngoro Mojokerto menyadari risikonya dan menerima risiko tersebut secara penuh dan menanggulangi sendiri risiko yang dihadapi karena tidak ada perusahaan asuransi yang bisa menanggung risiko seperti ini. 


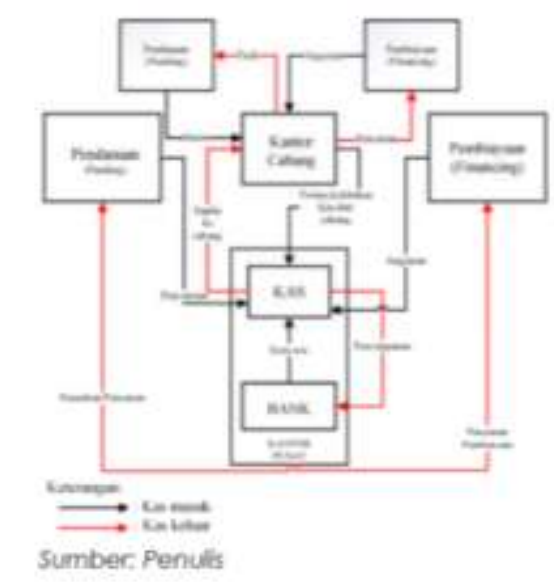

BMT Al IZZAH Ngoro Mojokerto menempatkan risiko likuiditas pada kuadran 3, di mana frekuensi terjadinya risiko likuiditas ini jarang dan bahkan belum pernah terjadi di BMT Al IZZAH Ngoro Mojokerto, namun ketika risiko likuiditas terjadi, maka dampak yang ditimbulkan besar. Pada kuadran ini, pihak manajemen harus merencanakan rencana kontijensi yang telah teruji untuk menjawab situasi saat risiko terjadi. Pada aktivitas pendanaan, mitigasi risiko yang dilakukan adalah dengan memberlakukan aturan penarikan tabungan melalui beberapa tahap. Tahap yang pertama adalah pelayanan penarikan hanya dapat di lakukan di kantor dengan menghubungi kasir BMT Al IZZAH Ngoro Mojokerto. Walaupun pada jam operasional, beberapa pegawai melakukan pelayanan di pasar-pasar, namun pelayanan itu terbatas hanya untuk menerima dana, seperti penyetoran tabungan, pembayaran angsuran. Hal-hal yang dapat di lakukan petugas saat melakukan layanan di luar kantor adalah konfirmasi penarikan kepada cabang terdekat pada batas nominal tertentu. Untuk transaksi di luar kantor, pada kasus ini di pasar-pasar, ketika ada anggota/calon anggota yang menginginkan penarikan simpanan, dapat konfirmasi kepada petugas yang sedang di lapangan untuk melakukan konfirmasi. Setelah di validasi, anggota/calon anggota dapat langsung ke kantor untuk mengambil uang tunai dengan mengisi slip penarikan serta membawa buku tabungan, atau dapat menunggu di tempat tersebut, sembari uang di antarkan dari kantor terdekat. Selain itu, untuk mengendalikan risiko likuiditas, untuk penarikan di atas Rp.10,000,000 (Sepuluh juta rupiah) di wajibkan untuk melakukan konfirmasi, baik melalui petugas, datang ke kantor terdekat, atau langsung menghubungi nomor telepon yang diberikan BMT Al IZZAH Ngoro Mojokerto setidaknya sehari sebelumnya. Tujuan dari diberlakukan prosedur sedemikian rupa agar segala transaksi dapat tercatat dengan baik. Teknik pencatatan yang baik berguna untuk melihat arus kas. Sehingga, dengan memiliki informasi yang cukup, maka BMT dapat melakukan antisipasi guna menentukan jumlah uang kas yang optimal. Selain itu, pentingnya konfirmasi agar pihak BMT dapat mempersiapkan kas yang di butuhkan. Pada sisi pendanaan, terdapat simpanan berjangka. Simpanan berjangka yang jatuh tempo akan di cairkan oleh pemilik dana. Pada kasus ini, pihak BMT melakukan komunikasi kepada pemilik dana untuk bisa memperpanjang simpanan berjangka yang dimiliki. Komunikasi yang dilakukan adalah menghimbau agar simpanan diperpanjang durasinya, lalu menanyakan alasan pencairan simpanan berjangka sekaligus menjelaskan manfaat apabila simpanan diperpanjang. Hal ini berguna bagi BMT untuk dapat mengurangi kas yang keluar dari aktivitas pencairansimpanan berjangka.

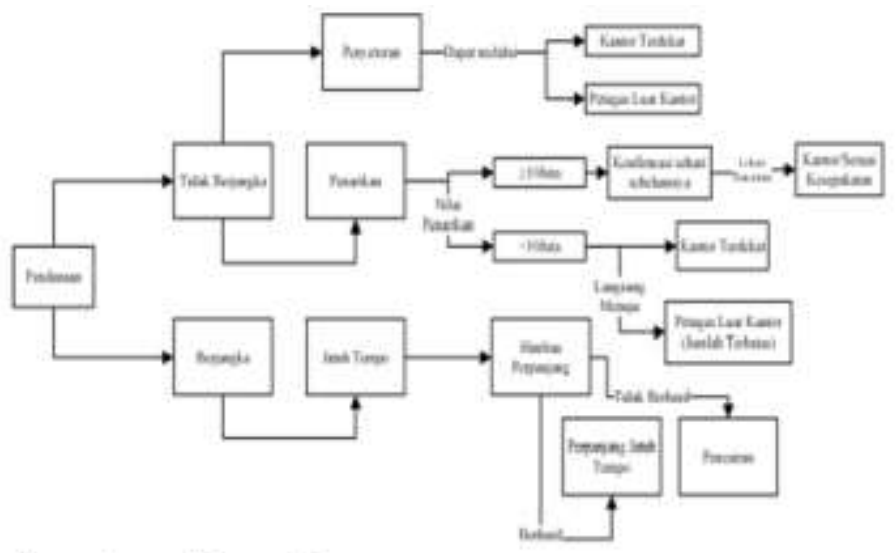


Untuk melakukan mitigasi risiko likuiditas yang berasal dari aktivitas antara kantor cabang dan kantor pusat, BMT Al IZZAH Ngoro Mojokerto melakukan berbagai upaya untuk melakukan pengendalian terhadap kas di setiap kantor cabang. Pengendalian kas pada setiap cabang dilakukan dengan cara membatasi kas yang tersedia di setiap kantor cabang. Pembatasan di dasarkan kepada total aset setiap cabang setiap harinya yang dilaporkan kepada kantor pusat. Tujuan dari melakukan pelaporan dan pengendalian kas tiap kantor cabang adalah untuk menjaga keamanan. Keamanan yang dimaksud adalah keamanan dari kantor cabang tersebut dari aksi pencurian. Selain itu, apabila kas dikendalikan oleh kantor pusat, maka ketika ada kantor cabang yang mengalami kekurangan, kantor pusat dapat dengan segera mungkin mengirim suplai uang kas kepada kantor cabang.
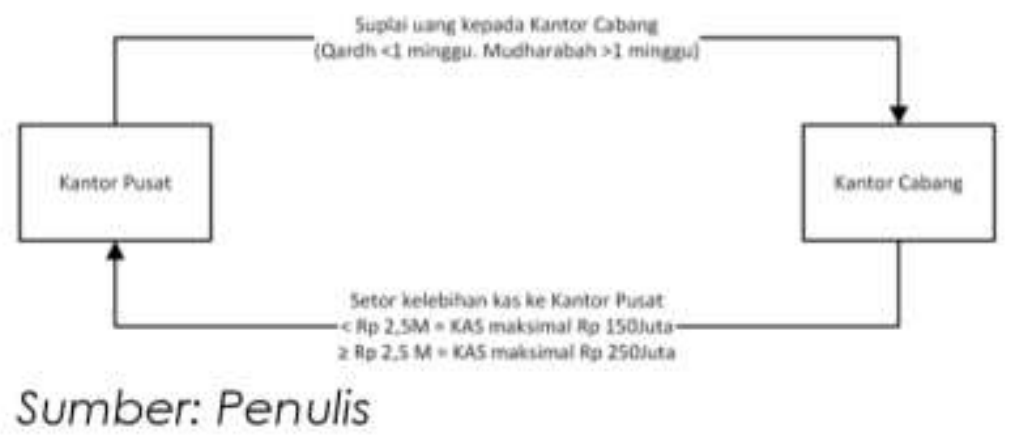

Gambar 5. Mitigasi dari Aktivitas Kantor Cabang

Pada BMT Al IZZAH Ngoro Mojokerto, dalam melakukan mitigasi risiko likuiditas, menerapkan tiga cara. Cara yang pertama adalah dengan menentukan batas maksimal pemberian pembiayaan berdasarkan aset. Prinsip dari penetapan limit maksimum pembiayaan kepada satu anggota/calon anggota pembiayaan adalah untuk mengurasi risiko dengan cara diversifikasi. Dengan memberikan pertimbangan untuk pembiayaan kepada satu anggota/calon anggota, kerugian dari risiko gagal bayar dapat diminimalkan sebab pada saat satu anggota mengalami kolektibilitas macet, kerugian dapat di batasi sesuai dengan batas maksimum pembiayaan yang diberikan. Sebab, risiko gagal bayar ini dapat menjurus kepada risiko likuiditas.

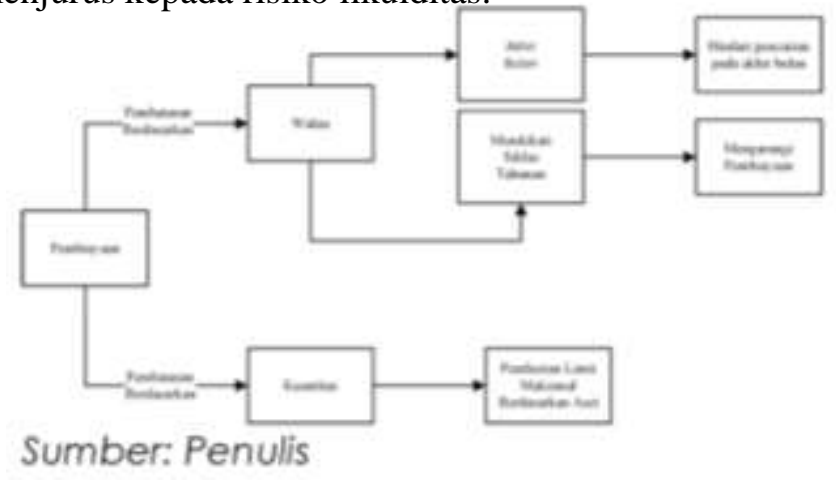

Gambar 6. Mitigasi dari Aktivitas Pembiayaan

Cara kedua adalah dengan menghindari pencairan pembiayaan pada akhir bulan. Tujuan dari menghendaki pencairan pembiayaan pada akhir bulan adalah agar pembiayaan yang diberikan tidak mempengaruhi rencana angsuran. Apabila rencana angsuran terganggu, maka pembiayaan yang diberikan akan terganggu, sehingga mempengaruhi rencana kas pada bulan berikutnya yang berpotensi menimbulkan risiko likuiditas.

Cara yang ketiga adalah melakukan pengurangan pembiayaan. Mitigasi Risiko dengan cara pengurangan pembiayaan dilakukan ketika memasuki waktu-waktu dimana permintaan akan likuiditas yang tinggi. Simpanan BMT pada bank merupakan salah satu alat likuid yang dapat menutupi kewajiban jangka pendek untuk menghindari risiko likuiditas yang mungkin terjadi. BMT Al IZZAH Ngoro Mojokerto memiliki komitmen yang kuat untuk memberikan kemudahan dalam melakukan 
penarikan simpanan yang dapat terjadi sewaktu waktu, walaupun di luar jam operasional dari BMT. Hal ini menimbulkan suatu risiko, dimana ketika kas yang tersedia pada BMT tidak mencukupi dan harus melakukan penarikan kas dari penempatan simpanan BMT pada Bank Umum Syariah (BUS). Untuk melakukan penarikan dalam jumlah yang besar ke bank, pihak BMT harus melakukan konfirmasi sebelumnya sesuai ketentuan dari bank yang bersangkutan. Untuk mitigasi risiko dari aktivitas konversi ini, tidak ada cara yang dilakukan untuk mitigasi risiko ini selain memperbaiki sistem untuk melakukan monitoring terhadap kas yang ada dan peramalan atas kas yang akan diperlukan di kemudian hari.

Ketika cara-cara di atas tetap tidak dapat menutupi kas yang diperlukan, BMT Al IZZAH Ngoro Mojokerto memiliki rencana-rencana darurat untuk menanggulangi risiko likuiditas yang dihadapi. Langkah yang ditempuh adalah dengan meminjam dana kepada perorangan. ketika BMT telah melakukan segala upaya pengendalian internal dalam rangka melakukan tindakan preventif sebelum risiko likuiditas terjadi. Maka upaya menanggulanginya dengan cara meminjam dana dengan menggunakan tabungan, Cara meminjam dana dengan menggunakan tabungan. Hal ini menarik, sebab apabila menghimbau secara perorangan untuk segera menabung (bagi yang memiliki tabungan sebelumnya) atau membuka tabungan (apabila sebelumnya belum menjadi anggota/calon anggota) otomatis tabungan yang diberikan ber-akad wadiah atau sebagai titipan. Artinya, dana yang di dapatkan tergolong dana murah, dimana pihak BMT hanya memberikan bonus yang tidak dipersyaratkan di awal. Secara ringkas berikut ini di gambarkan rencana kontijensi:

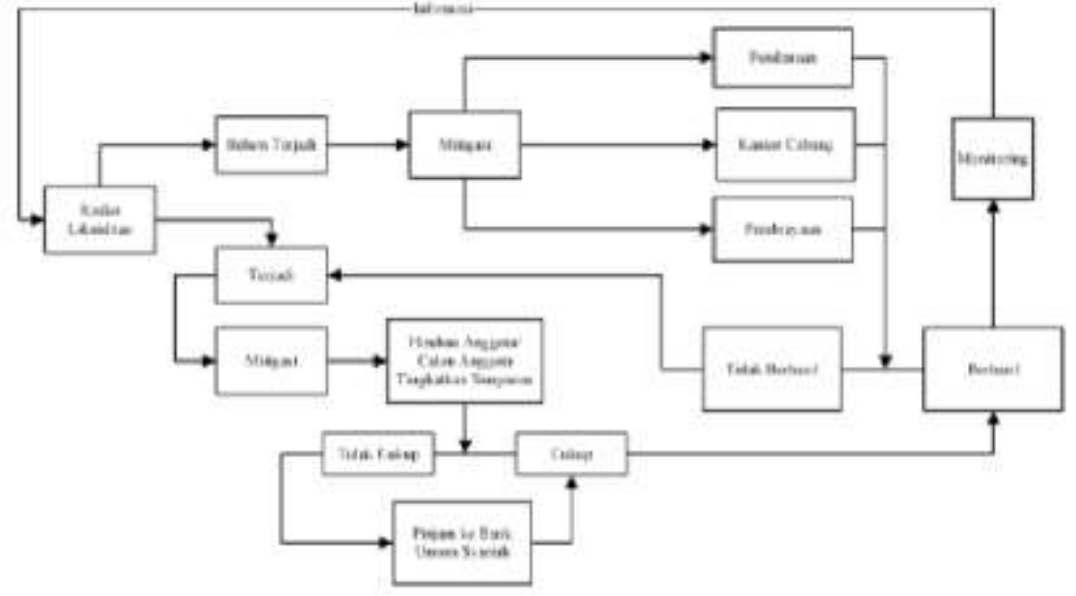

Sumber: Penulis

Gambar 7

Rencana Kontijensi Manajemen RisikoLikuiditas

Pengawasan dan pengendalian risiko likuiditas ini merupakan tahap penyempurnaan dari keseluruhan proses manajemen risiko likuiditas yang dilakukan. Pada BMT Al IZZAH Ngoro Mojokerto, selain pengawasan manual juga pengawasan dilakukan dengan bantuan teknologi. Teknologi digunakan untuk memberikan efisiensi dan kemudahan dalam melakukan koordinasi dan pengawasan kepada seluruh kantor cabang yang ada. Salah satu yang digunakan adalah sistem monitoring dengan menggunakan aplikasi Team Viewer. Dengan menggunakan aplikasi ini, kantor pusat dapat melihat aktivitas keuangan yang dilakukan oleh kantor cabang. Hal ini di tunjang dengan sistem pencatatan yang sudah terkomputerisasi, sehingga perubahan dapat di lihat secara realtime. Setiap cabang diwajibkan untuk laporan tiap hari terkait kondisi BMT. Selain laporan tiap hari, untuk mengetahui kondisi terkini dilakukan rapat sesuai dengan waktunya. Rapat terbagi atas rapat mingguan, rapat bulanan, dan rapat insidental. Rapat mingguan dilakukan di tiap kantor, baik kantor cabang dan kantor pusat dan di hadiri oleh seluruh kepala bagian di BMT. Tiap dua kali dalam seminggu, rapat mingguan dilakukan di kantor pusat dengan manajer dan seluruh kepala cabang. 
Rapat bulanan dihadiri oleh seluruh karyawan BMT, baik karyawan di kantor cabang masing-masing dan juga karyawan di kantor pusat. Rapat insidental merupakan rapat yang dapat dilakukan sewaktuwaktu oleh manajer, pengurus, dan pengawas. Tujuan dari dilaksanakannya rapat agar dapat mengidentifikasi masalah yang dihadapi secara cepat tanpa berlarut-larut dan saling bertukar pikiran sehingga memberikan solusi untuk menyelesaikan masalah tersebut. Lalu, dengan diadakannya rapat, maka hubungan antara-karyawan dengan karyawan semakin erat sehingga menghindari ketidakjujuran.

\section{SIMPULAN}

\section{A. SIMPULAN}

Berdasarkan dari hasil analisis penelitian yang dilakukan pada proses manajemen risiko likuiditas di BMT Al IZZAH Ngoro Mojokerto yang meliputi serangkaian proses seperti identifikasi risiko, penilaian risiko, mitigasi risiko, serta pengawasan dan pengendalian risiko likuiditas maka dapat disimpulkan bahwa:

a. Dalam melakukan proses identifikasi risiko, BMT Al IZZAH Ngoro Mojokerto masih berpedoman kepada data historis dan didapatkan pola dari siklus tahunan yang ada.

b. BMT Al IZZAH Ngoro Mojokerto menempatkan risiko likuiditas berada pada kuadran 3 di mana frekuensi terjadinya kecil, namun dampak yang ditimbulkan besar.

c. Dalam melakukan mitigasi risiko likuiditas, BMT Al IZZAH Ngoro Mojokerto memberikan perhatian lebih kepada langkah-langkah preventif agar risiko likuiditas bisa dihindari .

d. Untuk melakukan pengawasan dan pengendalian risiko likuiditas ini, BMT Al IZZAH Ngoro Mojokerto mengadakan rapat rutin dengan seluruh jajarannya dan dibantu dengan teknologi informasi untuk bisa menjangkau semua cabangnya secara optimal, efektif, dan efisien.

\section{DAFTAR PUSTAKA}

Agrawal, R. C. 2009. Risk Management. Jaipur: ABD Publisher.

Arifin, Zainul. 2005. Dasar-Dasar Manajemen Bank Syariah, Cetakan Ketiga. Jakarta: Pustaka Alvabet.

Arikunto, S. 1998. Prosedur Penelitian Suatu Pendekatan Praktek. Jakarta: PT. Rineka Cipta.

BMT Al IZZAH Ngoro Mojokerto. 2014. Neraca BMT ABC per 31 Juli 2014, 2013, 2012. Mojokerto: BMT ABC.

Daft, Richard L. 2007. Manajemen Edisi 6 Terjemahan oleh Edward Tanujaya dan Shirly Tiolina. 2007. Jakarta: Penerbit Salemba Empat.

Djazuli, A. 2006. Kaidah-kaidah Fikih: Kaidah-kaidah Hukum Islam dalam Masalah-masalah yang Praktis. Jakarta: Kencana.

Karim, Adiwarman A. 2006. Bank Islam Analisis Fiqih dan Keuangan Edisi Ketiga. Jakarta: PT. Raja Grafindo Persada.

Merna, Tony dan Faisal F. Al-Thani. 2005. Corporate Risk Management: An Organisational Perpective. Singapore: John Wiley and Sons (Asia) Pte Ltd.

Mudjib, Abdul. 2001. Kaidah-kaidah Ilmu Fiqh. Jakarta: Kalam Mulia. Republik Indonesia. Peraturan Menteri Negara Koperasi dan Usaha Kecil dan Menengah tahun 2007 nomor 35.3/Per/M.KUKM/X/2007 tentang pedoman pedoman penilaian kesehatan koperasi jasa keuangan 
Syariah dan unit jasa keuangan Syariah koperasi. 2007. Jakarta: Kementerian Negara Koperasi dan Usaha Kecil dan Menengah.

Rivai, Veithzal, dkk. 2007. Bank and Financial Institution Management: Conventional and Sharia System.

Soemitra, Andri, 2009. Bank dan Lembaga Keuangan Syariah edisi pertama cetakan kedua. Jakarta: Kencana Predana Media Group.

Sudarsono, Heri. 2008. Bank dan Lembaga Keuangan Syariah Edisi Ketiga. Cetakan Pertama. Yogyakarta: Ekonisia. 